\title{
HUMANIZAÇÃO DAS VÍTIMAS DO CONFLITO ARMADO COLOMBIANO EM COLORADO (FOTOGRAFIA), MOLANO (LITERATURA) E SALCEDO (PERFORMANCE)
}

\begin{abstract}
Juliana Leal ${ }^{1}$
RESUMO: Este artigo, resultado de uma pesquisa de pós-doutoramento na UFMG (2017), discorrerá sobre o processo de desterritorialização da população rural colombiana, fundamentalmente indígenas e afrocolombianos, sustentado pelo interesse de vários atores, entre eles, o Estado que, segundo Judith Butler (2016), ao invés de protegê-los, relega a eles, cada vez mais, uma condição de seres não enlutáveis. De vidas menos importantes que outras vidas. Abordarei o oposto desse gesto por meio da análise do processo de humanização que artistas colombianos como Alfredo Molano, Doris Salcedo e Jesús Abad Colorado oferecem às vítimas do conflito armado colombiano em algumas de suas obras. Palavras-chave: Conflito armado colombiano. Desterritorialização. Indígenas e afrocolombianos. Humanização. Arte.
\end{abstract}

Resumen: Este artículo, resultado de una investigación posdoctoral en la UFMG (2017), tratará del proceso de desterritorialización de la población del campo colombiana, fundamentalmente indígenas y afrocolombianos, estructurado por el interés de varios actores, entre ellos, el Estado que, según Judith Butler (2016), en lugar de protegerlos, les impone, cada vez más, una condición de seres no enlutables. De vidas menos importantes que otras vidas. Desarrollaré el opuesto de este gesto a partir del análisis del proceso de humanización que artistas colombianos como, Alfredo Molano, Doris Salcedo y Jesús Abad Colorado ofrecen a las víctimas del conflicto armado colombiano en algunas de sus obras.

Palabras-clave: Conflicto armado colombiano. Desterritorialización. Indígenas y afrocolombianos. Humanización. Arte.

Parte do problema da vida contemporânea é que nem todo mundo conta como sujeito Judith Butler (2016, p.54)

\footnotetext{
1 Professora Adjunta IV da Faculdade Interdisciplinar em Humanidades (FIH) da Universidade Federal dos Vales do Jequitinhonha e Mucuri - UFVJM - Campus de Diamantina/MG. E-mail: juhgleal@gmail.com.
} 


\section{INTRODUÇÃO:}

Desde o século $\mathrm{XV}$, em virtude da violenta e famigerada empresa de colonização europeia em terras americanas, que os povos originários da América Latina vêm resistindo sistematicamente a um processo de aculturação ou, para dizer de modo mais certeiro, a de seu duplo extermínio. Físico e espiritual. Físico e espiritual porque, segundo o antropólogo Eduardo Viveiros de Castro, o conceito de sociedade desses povos está estreitamente vinculado a um "todo orgânico", a "uma unidade corporada orientada por um valor transcendente", cujo modelo metafórico é o parentesco como princípio natural de constituição de pessoas morais coletivas" (2002, p.300). Em outros termos, uma comunidade, cujos fundamentos ontológicos-organizacionais se baseiam numa concepção holista do social, o que nos leva a substituir o termo "sociedade" por "cultura" (idem, p.298). Este conceito do social, a partir do comunitário, se contrapõe à figura do indivíduo integrado a um sistema ou organização social (concepção individualista do social), cujo modelo metafórico é o Estado constitucional e territorial (idem, p.300).

A vasta literatura etnográfica existente sobre as sociedades primitivas ${ }^{2}$, conforme assevera o antropólogo francês Pierre Clastres, tende a concluir a aversão destas pela violência, uma vez que nelas "o ser social primitivo se desenvolve fora do conflito armado, [pois] a guerra não pertence ao funcionamento normal, habitual das sociedades primitivas" (2004, p.159). Mas apesar disso, o que se tem visto desde o "descobrimento" suas culturas autóctones, uma "máquina de destruição de índios”, segundo Clastres, que conformaria o que, bem mais tarde, nomeariam de etnocídio, apesar da cunhagem deste termo ter sido realizada com um atraso de cinco séculos, a propósito da elaboração do conceito jurídico "genocídio" que batizou outra empresa racista de aniquilamento de humanos: a limpeza antissemita perpetrada pela Alemanha nazista no século XX. (idem, p.55-56)

A partir do modelo de "representação do ser social" assumido pelos colonizadores europeus de outrora, visão ironicamente não superada nos dias atuais, as culturas ameríndias, "gente sem fé, sem lei e sem rei”, segundo fizeram crer vários cronistas do século XVI, com raras exceções como

\footnotetext{
${ }^{2}$ Vale esclarecer que a expressão "sociedades primitivas" é usada por Pierre Clastres na obra em questão e não revela minha maneira de nomear e compreender ditas comunidades.

${ }^{3} \mathrm{O}$ antropólogo catalão Bartolomeu Melià revisita esse conceito, esclarecendo que a América não foi descoberta e sim “encoberta". Ele desenvolve este argumento na obra El don, la venganza y otras formas de economía guaraní, de 2004.
} 
Montaigne e La Boètie, segundo Pierre Clastres, estariam ainda em estado de natureza, portanto, ainda excluídas do estado de sociedade. Condição essa que só poderia ser superada a partir da figuração do Estado enquanto institucionalizador da vida social, o que muito beneficiaria ditas sociedades primitivas cuja imagem, na maioria das vezes violenta e belicosa, se amparava na representação reducionista da figura do guerreiro selvagem e bárbaro.

Essa secular prática etnocida em terras americanas, justificativa para a evangelização, civilização e ocidentalização desses povos, visto como pagãos, selvagens e bárbaros, atendia, outrora, a interesses comerciais expansionistas europeus, que atropelavam sem piedade, as formas de uso social e cultural do território ancestralmente ocupado pelas culturas originárias da América, visando saquear suas riquezas naturais e sequestrar suas terras. Hoje, a lógica de saqueio, roubo e expropriação de terras e riquezas teve ampliado o número de interessados: grandes latifundiários, carvoarias, multinacionais dos setores de exploração de minérios ${ }^{4}$, hidrocarbonetos e energia, donos do agronegócio e narcotraficantes, se tomamos o caso colombiano como exemplo. Para se ter uma ideia “A Colômbia é um dos países do mundo com maior concentração de terras em todo o mundo. Dados da Organização das Nações Unidas (ONU) mostram que, hoje, 52\% das propriedades rurais está nas mãos de 1,15\% da população" (PISMEL \& CHAGAS, s/d, p.27) e que "mais de três quartos dos municípios colombianos são predominantemente rurais. Eles ocupam $95 \%$ do território do país, onde vive um terço da população" (idem, p.28)

A partir da mecânica do pensamento neoliberal, em plena expansão no mundo, bem como pela negligência de Estados-Nações que, muito tardiamente, começam a reconhecer, em termos jurídico-constitucionais, as especificidades dos "direitos cidadãos" dos povos autóctones, o etnocídio das comunidades originárias, bem como da biodiversidade dos territórios por eles ancestralmente ocupados se perpetua a passos largos. Não raro, cabe enfatizar, com a anuência, direta ou indireta, de governos negligentes e corruptos, descaradamente avessos às necessidades das populações nativas que costumam ser as mais atingidas pela sanha capitalista-empresarial incentivada por seus dirigentes.

\footnotetext{
4 “A Controladoria Geral da República (CGR) demonstra que, pelo menos 40 milhões de hectares - cerca de um terço do território colombiano - estão sob interesses de exploração mineira” (PISMEL \& CHAGAS, s/d, p.34). "De acordo com a CGR, a atividade mineira, 'seja legal ou clandestina, muitas vezes se desenvolve em ecossistemas estratégicos para a conservação ambiental como páramos, bosques, pântanos, rios, várzeas, selvas, nascentes e aquíferos'. Do jeito que é realizada atualmente, a mineração antagoniza com a 'conservação ambiental e a vida dos habitantes dos territórios, incluídas as comunidades negras, indígenas, de colonos e camponeses’, aponta o estudo.” (idem, p.37)
}

Literatura e Cinema de Resistência, Santa Maria, n. 32: Manifestações estéticas dissidentes, jan.-jun. 2019, p. 55-86. - ISSN 1679-849X http://dx.doi.org/10.5902/1679849X36012 
Exemplos contundentes disso foram algumas medidas adotadas pela gestão do expresidente Álvaro Uribe (2002-2010) ${ }^{5}$ que, contrariando os interesses e necessidades da população, mas não aos do mercado internacional, especialmente o norte-americano, afastou o país de qualquer possibilidade de se integrar à ideologia de cooperação mútua que costuma permear os acordos comerciais entre países latino-americanos, vendendo-o a preço de banana para os interesses expansionistas econômico-militares estrangeiros. São eles:

1. o início da vigência, em 2012, do Tratado de Livre Comércio (TLC) pactuado entre a Colômbia e EUA, em 2006, pelos governos de Uribe e George Bush que consolidaram uma política neoliberal no campo forçando para baixo os preços dos produtos nacionais em razão da importação estadounidense, isenta de tributação (idem, p.30);

2. A

aprovação do Código de Minas, em 2001, que declarou a mineração como uma 'atividade de utilidade pública e de interesse social', permitindo a expropriação unilateral de terrenos que possuam riquezas minerais. A mesma lei eliminou a possibilidade de exploração direta do Estado no setor, que passou a ser realizada exclusivamente por empresas privadas. Restou ao poder público apenas a fiscalização e a regulação da atividade. A partir da aprovação do Código de Minas, o número de títulos para exploração mineira concedidos cresceu vertiginosamente. A média de concessões anuais, que não passava de 200 na década de 1990, chegou a 720 na primeira década dos anos 2000. (idem, p.35)

3. O incentivo do cultivo da palma africana (dendê) $)^{6}$, que ocupa 360 mil hectares das terras colombianas e o de cana-de-açúcar, 190 mil hectares, respectivamente utilizados na produção de biodisel e etanol. Segundo Pismel \& Chagas:

Os pesquisadores consideram que a expansão desordenada do cultivo de palma africana pode se tornar uma ameaça à segurança alimentar das regiões. Segundo eles, a monocultura de palma pode diminuir a diversidade de cultivos agrícolas que garantem a produção de alimentos. $\mathrm{O}$ aumento da produção, incentivado por isenções fiscais e altos preços no mercado internacional, também pode entrar em conflito com áreas de preservação e com a proteção da biodiversidade. Há casos, como o da região do Catatumbo, em que a introdução do cultivo de palma por grandes empresários, com financiamento estatal, esteve associada à atuação de grupos paramilitares e violações de direitos de camponeses. 'O paramilitarismo é cúmplice do Exército e do Estado. É uma política do Estado colombiano, que usou como justificativas para entrar na região a

\footnotetext{
5 "Os oito anos do governo Uribe foram marcados pela maior ofensiva militar do Estado contra a insurgência armada. No período, também cresceram os casos de perseguições e ameaças a civis do movimento social, judicializações e assassinatos de lideranças. As zonas de reserva [ZRCs] de todo o país foram desativadas, porque Uribe as considerava territórios guerrilheiros." (idem, p.50)

6 "Matéria-prima para produção de biocombustível e de azeites. Foi introduzida na Colômbia nos anos 30 pela United Fruit Company, mas seu cultivo cresceu vertiginosamente a partir do final dos anos 1990. Produto típico de monocultivos, pode prejudicar a biodiversidade da região. A expansão das áreas de cultivo está comumente associada a casos de deslocamentos forçados de famílias camponesas." (idem, p.7)
} 
guerrilha e a coca. Mas isso não é verdade. Buscava unicamente dizimar o movimento social e garantir a segurança para a entrada de empresas multinacionais na região', conta Quintero, líder camponês da Ascamcat. (idem, p.38-39)

Vale esclarecer que a população camponesa colombiana, por não possuir titulação de suas terras, em termos constitucionais ${ }^{7}$, fica ainda mais vulnerável que as comunidades indígenas e afrodescendentes ${ }^{8}$ em relação às garantias de permanência e titularidade de seus territórios. Segundo representante da ANZORC (Associação Nacional das Zonas de Reserva Camponesa (ZRC) ${ }^{9}$ ), a qual integram 50 organizações camponesas colombianas, os camponeses reivindicam uma garantia jurídica ${ }^{10}$ para que possam ocupar 10 milhões de hectares de terra estatal sem que sejam despejados pela pressão do latifúndio ou dos interesses das mineradoras estrangeiras (idem, p.27) ${ }^{11}$, já que o país utiliza "apenas 4,9 dos 21,5 milhões de hectares, aptos para produção agrícola, pouco mais de um quinto do total disponível" (idem, p.33)

\footnotetext{
7 “as FARC, na mesa dos diálogos de paz, em Havana, formalizaram uma proposta que pede a destinação de 9,5 milhões de hectares para as ZRC" (idem, p.46). "Atualmente, $40 \%$ dos proprietários rurais não têm escritura" (idem, p.45).

8 "Atualmente, existem 166 territórios reservados a comunidades afrodescendentes reconhecidos pelos Incoder, que somados abarcam a área de 5,2 milhões de hectares, segundo o Departamento Administrativo Nacional de Estatísticas (DANE). As comunidades negras se localizam principalmente nos litorais do Pacífico e do Caribe, além dos vales interandinos. Por sua vez, as reservas indígenas são 756 e abrangem uma área total de 31,5 milhões de hectares, em 25 dos 32 estados colombianos. Os dados são do Incoder." (idem, p.46)

${ }^{9}$ Sobre as ZRCs, afirma Juan Carlos Quintero, do Catatumbo: "são uma alternativa para que por fim tenhamos um acesso seguro à terra, para que possamos permanecer nos territórios que organizamos, conservamos, para manter nossos modos de vida e preservar nossa cultura, nossa economia e nossas formas organizativas" (idem, p.48). "Atualmente existem seis ZRC formais - constituídas pelo governo entre novembro de 1997 e dezembro de 2002 -, que juntas abarcam uma área de cerca (sic) 890 mil hectares. São elas: Guaviare (469 mil ha); Pato-Balsillas, (145 mil ha); Sur de Bolívar (29 mil ha); Cabrera (44 mil ha); Pérola Amazônica - Bajo Cuembí e Comandante (22 mil ha) e Vale do Rio Cimitarra (184 mil ha)" (idem, p.49). Essas Zonas foram criadas a partir da lei 160 de 1994, sancionada pelo então presidente colombiano César Gaviria Trujillo (1990-1994), embora sua regulamentação tenha acontecido apenas em 1996, a partir do decreto 1776 que delegou ao Incora (Instituto Colombiano de Reforma Agrária) a seleção das áreas geográficas para formar as zonas de reserva. (idem, 56-57). Infelizmente a tentativa do Incora foi freada em 2002 quando Álvaro Uribe chega à presidência do país. "O Governo liquidou o programa piloto, cortou financiamentos e investimentos previstos, o que significou a impossibilidade de qualquer avanço das seis ZRC constituídas ou o surgimentos de novas" (idem, p.58, grifo meu). Em 2007 Uribe aprova no Congresso o Estatuto de Desenvolvimento Rural que praticamente extiguia as ZRC. Em 2009 o Estatuto foi declarado inconstitucional pela Corte Constitucional, o que fez com que a lei 160, de 1994 voltasse a vigorar. (ibidem, grifo meu)

10 “Apesar de tratar da questão da terra e do trabalhador agrário em diversos artigos, a Constituição [colombiana de 1991] não reconhece a figura do camponês como sujeito de direito. A possibilidade de criação de territórios autônomos, como as ZRC, ficou restrita aos indígenas e aos afrocolombianos." (idem, p.56)

${ }^{11}$ Como já dito aqui, há no território colombiano apenas seis ZRC constituídas e reconhecidas pelo Estado, que abrangem um montante de 893 mil hectares. (idem, p.28).
} 
Assim, ao desvirtuarem o conceito fundante do termo Pachamama ${ }^{12}$ em torno do qual a terra é vista como lugar sagrado de transmissão e perpetuação da vida, isto é, das práticas e saberes culturais de um povo, os europeus (de outrora), bem como grandes empresários do agronegócio, latifundiários pecuaristas ${ }^{13}$, narcotraficantes e multinacionais (de hoje) alteram drasticamente a estrutura da terra passando a compreendê-la tão somente enquanto lugar para produção de excedente comercial. O famigerado lucro, que tem perseguido, matado, oprimido e expulsado aproximadamente seis milhões de civis de seus lares nas últimas cinco décadas na Colômbia. ${ }^{14}$

Judith Butler afirma, no livro Quadros de guerra, que "uma vida específica não pode ser considerada lesada ou perdida se não for primeiro considerada viva”. (2016, p.13) E acrescenta: uma vida só pode ser reconhecida como vida se for enlutável, ou seja, ser for passível de luto. “Apenas em condições nas quais a perda tem importância o valor da vida aparece efetivamente. Portanto, a possibilidade de ser enlutada é um pressuposto para toda vida que importa” (idem, p.32). E esse movimento de reconhecimento do que é vivo se daria, segundo ela, a partir de uma compreensão ontológico-social de corpo cujos termos norteadores do reconhecimento dos sujeitos são produzidos e deslocados a partir da repetição das normas que os constituem. Normas que se encontram permanentemente em mudança, sempre em razão das operações de poder (idem, p.17) que tornam “certos sujeitos 'reconhecíveis' e outros mais difíceis de reconhecer” (idem, p.20). No entanto, ela problematiza a definição do enquadramento dessas normas ao incluir a "condição precária" como variável para que uma vida possa ser efetivamente vivível (idem, p.40). E essa precariedade, em sua opinião, deveria se pautar em termos de igualdade, portanto tomada enquanto "precariedade compartilhada" (idem, p.50) que convidaria a "uma universalização mais sólida dos direitos” (ibidem). Esse caráter de igualdade advindo da generalização de sua condição (idem, p.42) diz respeito às condições sociais e políticas, externas a nós, que nos fazem ou não precários e que oferecem ou não suporte efetivo à manutenção da vida. Diz Butler:

Não há vida sem condições de vida que sustentam, de modo variável, a vida, e essas condições são predominantemente sociais, estabelecendo não a ontologia distinta da pessoa,

\footnotetext{
12 Pachamama é um termo advindo do quéchua que significa "Mãe Terra". Pacha, terra ou mundo e mama, mãe.

13 "Se faltam terras para a grande maioria dos colombianos, as criações de gado do país têm espaço de sobra. Em $80 \%$ dos 39,2 milhões de hectares empregados em pastagem há apenas uma cabeça de gado por hectare.” (idem, p.33)

${ }^{14}$ Uma das alternativas encontradas para subsistência de 60 mil famílias colombianas no campo é o cultivo de folha de coca que se extende por 48 mil hectares no país. (idem, p.31) "Ao contrário da Bolívia e do Peru, onde a coca é uma tradição milenar da cultura inca, na Colômbia a planta é cultivada basicamente para a produção de cocaína” (ibidem)
} 
mas a interdependência das pessoas, envolvendo relações sociais reproduzíveis e mantenedoras, assim como relações com o meio ambiente com formas não humanas de vida, consideradas amplamente. Esse modo de ontologia social (para o qual não existe nenhuma distinção absoluta entre o social e o ecológico) tem implicações concretas para a maneira pela qual voltamos a abordar as questões relativas à liberdade reprodutiva e às políticas antibélicas. A questão não é saber se determinado ser é vivo ou não, nem se ele tem o estatuto de "pessoa"; trata-se de saber, na verdade, se as condições sociais de sobrevivência e prosperidade são ou não possíveis. (idem, p.38, grifos meus)

Ao problematizar as condições que tornam a vida possível, Butler introduz a ideia de vida como "um processo condicionado e não como um aspecto interno de um indivíduo monádico ou qualquer outro construto antropocêntrico" (idem, p.43). E arremata dizendo que "essas condições são nossa responsabilidade política e a matéria de nossas decisões éticas mais árduas” (ibidem).

Ainda sobre a "condição precária" e sua maximização a partir do papel que o Estado-Nação deveria exercer em contraposição ao que ele efetivamente exerce na garantia ou violação das condições de vida dos sujeitos, diz Butler:

A condição precária designa a condição politicamente induzida na qual certas populações sofrem com redes sociais e econômicas de apoio deficientes e ficam expostas de forma diferenciada às violações, à violência e à morte. Essas populações estão mais expostas a doenças, pobreza, fome, deslocamentos e violência sem nenhuma proteção. A condição precária também caracteriza a condição politicamente induzida de maximização da precariedade para populações expostas à violência arbitrária do Estado que com frequência não têm opção a não ser recorrer ao próprio Estado contra o qual precisam de proteção. Em outras palavras, elas recorrem ao Estado em busca de proteção, mas o Estado é precisamente aquilo do que elas precisam ser protegidas. Estar protegido da violência do Estado-Nação é estar exposto à violência exercida pelo Estado-Nação; assim, depender do Estado-Nação para a proteção contra a violência significa precisamente trocar uma violência potencial por outra. Deve haver, de fato, poucas alternativas. É claro que nem toda violência advém do Estado-Nação, mas são muito raros os casos contemporâneos de violência que não tenham nenhuma relação com essa forma política. (idem, p.46-47, grifos meus)

Assim, a figuração do Estado como “institucionalizador da vida social”, severamente imposta à lógica ontológico-organizacional dos povos originários da América, em especial na Colômbia, foco deste trabalho, não somente não garantiu a pretensa vida em sociedade que os restituiria de sua "condição selvagem, belicosa e bárbara", mas tem, há séculos, e de modo irrefreável, os destituído de sua condição de seres enlutáveis, de vidas vivíveis, de vidas passíveis de reconhecimento enquanto vidas. Pode-se apontar como exemplo contundente disso o fato de que somente em 1991, o Estado colombiano passa a incluir, em sua Constituição Política, a faceta da diversidade étnica e 
cultural de sua Nação (artigo 7), prometendo não somente reconhecê-la, mas protegê-la. Para se ter uma ideia, segundo a ONIC (Organización Nacional Indígena de Colombia) há na Colômbia 102 povos indígenas e 65 idiomas, o que revela uma inquestionável multiplicidade cultural ali presente, que vem sendo infelizmente invisibilizada há séculos.

Dita Constituição reafirma o compromisso, nos artigos 09 e 227, especialmente, de priorizar a promoção da integração econômica, social e política com as demais nações da América Latina e do Caribe para "conformar uma comunidade latino-americana de nações" (artigo 227). Meta nacional posta claramente em oposição às decisões, negociatas e acordos econômicos que vêm, há décadas, facilitando o trânsito em território colombiano de multinacionais e megaprojetos econômicos, principalmente acordados entre os Estados Unidos ${ }^{15}$, o que sinaliza claramente que "questões nacionais são moduladas pelas questões de política externa” (BUTLER, 2016, p.49).

A despeito disso e do conteúdo do artigo 63 da Constituição de 1991 que diz que "Os bens de uso público, os parques naturais, as terras comunais de grupos étnicos, as terras de resguardo, o patrimônio arqueológico da Nação e os demais bens que determine a lei, são inalienáveis, imprescritíveis e impenhoráveis", há mais de seis séculos que a questão que se interpõe entre os povos originários de toda a América Latina tende a ser a mesma: a luta pela terra (território, para seus verdadeiros donos) e pelo usufruto de toda a riqueza nela contida: água, matas e outros recursos naturais, elementos indispensáveis para a sobrevivência e autonomia desses grupos, bem como para a manutenção de práticas culturais ancestrais no seio das quais se fundamentam e se estruturam o sentido de coletividade entre seus membros. Luta por vezes interceptada por outra prerrogativa constitucional (artigo 59) que dá ao Governo Nacional direitos de expropriar terras, sem prévia indenização, de modo a "atender às necessidade e requerimentos de um estado de guerra", configurando um quadro de políticas e práticas governamentais contrárias aos interesses ideológicos, ontológicos e organizacionais

\footnotetext{
15 “Ainda sobre a posição contrária do Estado colombiano em relação aos interesses políticos da comunidade latino-americana e da comunidade internacional contra a qual os EUA combate ferrenhamente, cabe relembrar que a: "Colômbia foi o único país da América Latina que enviou tropas para combater na guerra da Coreia em 1951, ao lado dos Estados Unidos, o que levou à aclamação dos Estados Unidos para exigir a expulsão de Cuba da OEA em 1962; o único país da América Latina que, ao lado dos Estados Unidos, não apoiou a Argentina na guerra das Malvinas em 1983, e o único país da América Latina que em 2002 respaldou os Estados Unidos na sua 'guerra preventiva' contra o Iraque. É claro que a dependência da Colômbia aos Estados Unidos, nos campos político, econômico, militar e da política internacional, é total, incondicional, permanente e contrária aos interesse da América Latina." (SUESCÚN, 2010, p.4, tradução minha).
} 
dessas comunidades (indígena e afrodescendente) que enxergam a palavra território muito além de seu valor comercial.

O que se vê em toda a extensão da geografia territorial colombiana é um sistemático e desumano processo de desterritorialização da população rural, composta por indígenas e afrocolombianos, movido por interesses de grandes grupos empresariais, de narcotraficantes e de uma acirrada disputa política entre grupos guerrilheiros de extrema esquerda e extrema direita, não raro fomentado por forças do Exército Nacional. Essa diversidade de atores no conflito armado tem suas raízes durante o período da Violencia (com maiúscula), ocorrida nos anos cinquenta, e cujo detonador foi o assassinato do então candidato à presidência, o liberal democrata reformista Jorge Eliécer Gaitán, no dia 9 de abril de 1948. O enfrentamento entre liberais e conservadores, os dois partidos políticos que dividiam a preferência eleitoral da população colombiana, causou inúmeras mortes e, a partir daí que:

Desde meados dos anos sessenta, com a criação de várias guerrilhas, entre elas as FARC e o ELN, que continuam ativas meio século depois, [a] Colômbia entrou em outro vórtice de violências, que chegaram a seu clímax nos anos noventa e a começos da década de 2000. (RESTREPO, In: COLORADO, 2015, p.13, tradução minha)

Segundo Ortiz \& Kaminker, no entanto, a problemática dos desterritorializados colombianos poderia ser dividida em três marcos históricos, cujo momento inicial se daria a partir dos anos oitenta até os dias atuais:

Com respeito à migração forçada é possível identificar três momentos ou fases nas quais a violência política ocasionou a saída massiva de colombianos nos últimos trinta anos. Num primeiro momento, 1984-1995, a repressão teria como objetivo o aniquilamento das organizações políticas alternativas surgidas no marco dos diálogos de paz de meados dos anos oitenta. Neste período a luta contra-insurgente englobaria o acionar das forças armadas. O segundo momento, 1996-2005, se caracterizaria pelo despovoamento e repovoamento das regiões consideradas de influência guerrilheira, ao qual se somaria dois fatores que complexificam o conflito interno: a expansão do paramilitarismo e o fenômeno do narcotráfico. Durante os anos noventa, a luta contra-insurgente ficará velada pela "guerra contra o narcotráfico". O terceiro momento, desde 2006 até a atualidade, se evidencia a consolidação do paramilitarismo como força política e a perseguição sistemática aos defensores de direitos humanos e aos críticos da política de guerra total. Neste período se falará de "guerra contra o terrorismo" (2014, p.38, tradução e grifos meus)

Literatura e Cinema de Resistência, Santa Maria, n. 32: Manifestações estéticas dissidentes, jan.-jun. 2019, p. 55-86. - ISSN 1679-849X http://dx.doi.org/10.5902/1679849X36012 
No gráfico 1, apresentado abaixo, podemos perceber esses três períodos históricos em termos quantitativos de suas vítimas. Vale observar que nos anos iniciais da gestão do expresidente Álvaro Uribe (2002-2010) o gráfico atinge seu ponto mais elevado, perfazendo um montante de 618.058 pessoas desterritorializadas em território colombiano.

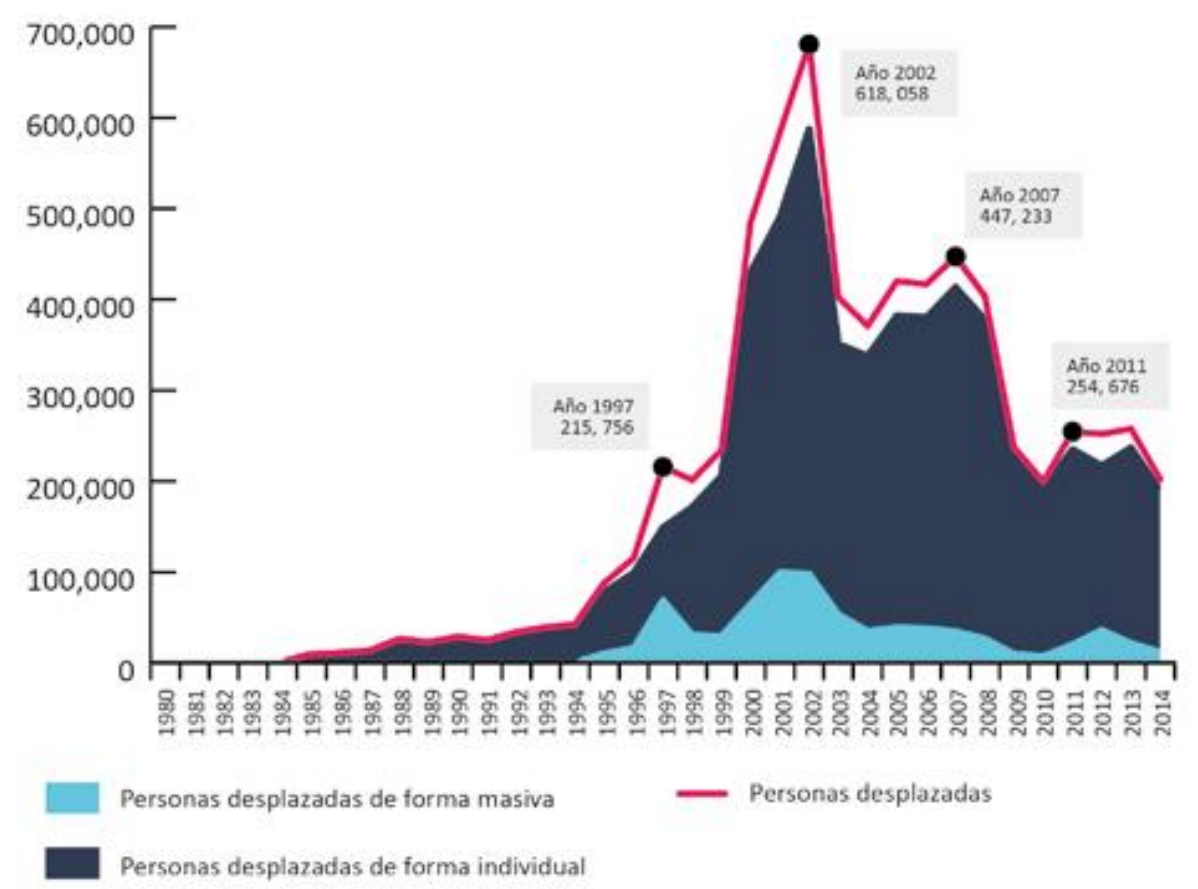

Gráfico 1: Evolução do número de pessoas desterritorializadas forçosamente na Colômbia (1980-2014) ${ }^{16}$

Outro segmento étnico diretamente afetado pelo conflito armado são os afrocolombianos. Vitimados por uma espécie de exílio triplo, "um estado de ser descontínuo" (SAID, 2003, p.50) que remonta às origens do processo de saída compulsória dos povos africanos de seu continente (terra natal), à proibição do uso pleno de seus idiomas (raízes) e à "fratura incurável” (idem, p.46) no exercício pleno dos laços comunitários (passado), esse segmento populacional convive, junto com os grupos étnicos indígenas colombianos, com a marginalização social e a desumanização. Termo este tomado aqui a partir da ideia de destituição da condição humana provocada pelo exílio, resultante da "negação da dignidade e da identidade das pessoas" (idem, p.48) e da "solidão vivida fora do grupo: a privação sentida por não estar com os outros na habitação comunal” (idem, p.50). Por essa razão o

${ }^{16}$ SABOGAL et. al, 2015, p.57. 
exílio pode ser compreendido como uma "vida levada fora da ordem habitual. É nômade, descentrada, contrapontística" (idem, p.60)

Apesar de ser conhecida com uma das democracias mais antigas da América Latina a Colômbia, ou mais especificamente o Estado colombiano, há mais de meio século, vem infringido, de modo sistemático e ininterrupto, uma série de direitos humanos, particularmente entre cidadãos de origem indígena ${ }^{17}$ e afrocolombianos, perfazendo um montante de 181 mil civis mortos no conflito armado desde 1958. Alguns desses direitos, apesar de figurarem na Constituição de 1991 e de serem objeto de pactuação em diversas convenções e acordos internacionais, são sistematicamente ignorados pelo Estado colombiano, colocando o país num estado de guerra permanente, amparado por uma impunidade transmitida, como uma espécie de herança maldita, de governo a governo. Ano após ano. Só para se ter uma pequena ideia da gravidade da situação, "a Corte Constitucional colombiana nos autos 004 de 2009 e 382 de 2010 declarou que existem 35 povos indígenas sob risco de extinção física e cultural", segundo consta em relatório do Alto Comisionado de las Naciones Unidas para los Refugiados (ACNUR) de 2012, de um montante de 87 etnias, distribuídas em 27 Estados do país, cujo número de indígenas que as integra gira em torno de 500 mil.

Nesse sentido, a ideia de barbárie forçosamente vinculada aos povos originários não serviu para outra coisa senão para justificar a violência da empresa colonizadora de outrora e da sanha neoliberal do Estado colombiano que resiste disfarçada sob o véu da ocidentalização e/ou civilização e, mais recentemente, sob a perversa justificativa da lógica da livre concorrência ou da ampliação dos mercados. Práticas que não fizeram senão perseguir, oprimir, escravizar, humilhar e anular as possibilidades de realização plena dos modos de viver, ser e saber das culturas ameríndias, desde o século XV.

Segundo o caderno Colombia: violencia y derechos humanos (2005), o conflito social e armado colombiano é um dos mais antigos da América Latina e é fundamentalmente perpetrado pelas forças armadas e por grupos paramilitares, amparado pelo acirramento da disputa político-partidária entre liberais e conservadores que, desde começos do século XX, divide posições e justifica mortes, perseguições e ameaças à população civil. Esse “Terrorismo de Estado" (idem, p.3), segundo adjetiva

\footnotetext{
${ }^{17}$ Segundo dados de relatório da ACNUR de 2012 "Os indígenas na Colômbia representam 2,74\% do total da população colombiana e 3,4\% dos quase 3.900.000 de desterritorializados internos” (tradução minha).
}

Literatura e Cinema de Resistência, Santa Maria, n. 32: Manifestações estéticas dissidentes, jan.-jun. 2019, p. 55-86. - ISSN 1679-849X http://dx.doi.org/10.5902/1679849X36012 
o referido caderno, desenha um quadro político-social de extrema gravidade, alicerçado por violações crescentes, generalizadas e sistemáticas de direitos que, a despeito de serem registrados e publicizados por organizações nacionais e internacionais de direitos humanos, não dão conta de fazer cessar essa dinâmica mortuária contabilizada em estatísticas alarmantes.

Como não entender essa sistemática perversa de mutilamento ou extermínio sociocultural, produzida no seio do século XX, e que se arrasta sem cessar século XXI a dentro, como sócia da empresa colonizatória de séculos anteriores? Processo que não faz senão acumular cifras monstruosas de desterritorializados - dentro e fora do território colombiano - despojados de seus lares, de suas comunidades e de seus territórios (espaços emblemáticos de memória e afeto), bem como de todos os elementos, signos, práticas, saberes e fazeres que os compõem.

A concepção de ser social entendida a partir do Estado como figura centralizadora e reguladora da vida social de um povo, em contraposição ao predicado selvagem do ser em estado natural dos "povos primitivos" não poderia figurar como argumento sustentador de um caráter civilizatório na Colômbia do século XX e XXI, já que a legalização do paramilitarismo no país parece claramente passar pelo crivo do próprio Congresso da República. A aprovação da Ley de Justicia y Paz, de 21 de junho de 2005, ou Ley 975, firmada pelo então presidente Álvaro Uribe Vélez, é um exemplo contundente de uma regulamentação "republicana" que "pretende firmar com os que cometem crimes atrozes, um pacto de impunidade, deixando sem castigo os responsáveis desses feitos, desconhecendo as vítimas e ocultando a verdade do ocorrido" (Corporación de Servicios Jurídicos Profesionales Comunitarios SEMBRAR, 2005, p.5, tradução minha)

Além disso, foram promulgadas outras leis, ao longo das últimas quatro décadas, nesse país, tais como El Estatuto de Seguridad (1978), Estatuto para la Defensa de la Democracia (1988), Estatuto para la Defensa de la Justicia (1991) e a Ley antiterrorista (2001) que exacerbam ainda mais a impunidade, o desmando, a perseguição política e a arbitrariedade do Estado e seus aparelhos regulamentadores nos processos jurídicos relativos às questões sobre o conflito armado no país:

O Estatuto de Segurança, promulgado em 1978, outorgou faculdades ilimitadas à força pública para buscar, apreender ou prender sem ordem judicial. Neste período se incrementaram as torturas, as execuções extrajudiciais e o desaparecimento forçado. Em 1988 foi emitido o Estatuto para a Defesa da Democracia, que deu origem aos tribunais militares que julgaram de forma sumária milhares de opositores, sem as mínimas garantias processuais. No marco da Constituição de 1991 foi criado o Estatuto para a Defesa da Justiça, com o qual se desenvolve a justiça regional focada em assumir os casos de terrorismo, narcotráfico e 
violência política, desatando a perseguição aos ativistas sociais e a penalização do protesto social. Finalmente, no ano de 2001, tem início a Lei antiterrorista que amplia ainda mais as prerrogativas da força pública (busca, apreensões e prisões sem mandato judicial), envolve a população civil no conflito e ocasiona novos mecanismos de impunidade. A pesar de esta lei ter sido declarada ilegal, continua sendo aplicada em todas as regiões do país. (idem, p.4, tradução minha)

Esses são alguns exemplos de que a figura do Estado, noção perspectivada pela cultura ocidental, ao tentar aferir status civilizatório aos povos ameríndios e, por extensão, às "minorias" culturais colombianas, lhes amputa não somente a autonomia enquanto comunidade tradicional mas lhes destitui de sua condição humana, de sua condição de seres enlutáveis, segundo Butler, aspecto que lhes distingue como seres vivos, como vidas vivíveis e reconhecíveis. Condição essa que lhes permitem ser identificados enquanto seres em posse do direito à vida, bem como das condições sociais e políticas que possibilitam que essa vida seja possível (segurança, território, laços comunitários, etc.), que lhes deem, em suma, suporte para sua manutenção. Os povos considerados violentos e belicosos, na mentalidade de alguns pensadores do século XVI, a partir desse raciocínio, são, em tempos atuais, irrevogavelmente vítimas que deveriam, pelo mesmo Estado que as condena, persegue e extermina, receber amparo jurídico e social para que as condições indispensáveis à manutenção de suas vidas existam e sejam efetivamente garantidas.

Essa mecânica perversa de condenação e invisibilização ontológica do outro, perpetrada vergonhosamente pelo Estado-Nação, parece estar estreitamente relacionada à expressão "esvaziamento ontológico da vida", que diz respeito às estratégias políticas usadas pelo poder para sua modelagem (SAFATLE, 2015, p.413), para “despossessão dos sujeitos”. Este conceito é elaborado pelo professor Vladmir Safatle a partir da análise que faz da articulação travada entre o biológico e o social, a biopolítica. A biopolítica se refere à compreensão do social pelo poder soberano a partir do uso de técnicas, instrumentais e mecanismos biológicos, conferindo à política a qualidade de um campo dentro do qual os indivíduos não possuem predicados (idem, p.413-414). Os sujeitos são reduzidos, dentro desse raciocínio, a uma massa compacta, a um organismo dentro do qual suas singularidades ou especificidades não são consideradas. Destitui-se do ser o reconhecimento de atributos particularizantes em prol de um movimento homogeneizante de condutas, mais facilmente controláveis e manipuláveis.

Literatura e Cinema de Resistência, Santa Maria, n. 32: Manifestações estéticas dissidentes, jan.-jun. 2019, p. 55-86. - ISSN 1679-849X http://dx.doi.org/10.5902/1679849X36012 
A biologização da política ou biopolítica se associa, portanto, às estratégias disciplinares que administram corpos e que reduzem os conflitos decorrentes das estruturas sociais a patologias que devem ser extirpadas, simplificando as organizações sociais por meio de uma ideia de totalidade social, de defesa de uma "corporeidade do social", pois "a vida será o fundamento da Lei porque a Lei encontrará na vida sua própria imagem invertida" (idem, p.415). Em outros termos, a política, campo complexo de administração de conflitos de interesses de diversos segmentos sociais, seria regida por um raciocínio que simplifica particularidades de interesse, deslegitimando o amplo e complexo campo de diversidade social e cultural inerente às sociedades latino-americanas.

A concepção de comunidade dos povos originários, calcada a partir da figura do ser coletivo se confronta com o lugar do ser individual (do indivíduo) das sociedades modernas. No entanto, a partir da concepção dos Estados-Nações, com suas respectivas cartas constitucionais, passou-se a falar em cidadania e direitos cidadãos. Os povos originários, indígenas e afrocolombianos, dentro dessa lógica, precisaram e ainda precisam ser “contemplados”, reconhecidos, para que seus territórios, núcleo central para realização plena de suas práticas, fazeres e saberes, não fossem e não sejam confiscados ou expropriados. Entretanto, como entendê-los dentro de um marco de sociedade regido por um EstadoNação que concebe seus cidadãos como indivíduos despossuídos, visão claramente oposta à compreensão de sujeito que se efetiva coletivamente, em termos comunitários, a partir de uma lógica holista da vida? Essa pergunta "entra em conflito com a ideia tradicional dos direitos humanos como direitos dos indivíduos, e também com um entendimento homogêneo da nacionalidade" (HUYSSEN, 2014, p.206). Por isso:

construir um binário irreconciliável entre os direitos humanos universais, como direitos apenas dos indivíduos, e os direitos culturais, como direitos de grupos étnicos ou raciais, traz o risco de rejeitar os direitos individuais dos membros dos grupos em nome da cultura. Seria igualmente inaceitável, contudo, desconhecer indivíduos autônomos, como se pudesse existir autonomia fora das relações sociais. (idem, p.209)

O problema que se interpõe a essa compreensão homogeneizante e higienista da vida pelo Estado-Nação colombiano se assemelha a que subjaz ao conceito de "éthos coletivo" na contemporaneidade e a tensão existente entre ele e a moral, apresentada por Judith Butler na obra Relatar a si mesmo: crítica da violência ética. A moral, segundo Adorno (apud BUTLER, 2015, p.1417), se realiza e se aperfeiçoa na razão direta do enfraquecimento do éthos coletivo, que pressupõe uma 
falsa ideia de unidade e de universalidade em relação ao conjunto de hábitos, crenças e costumes comportamentais. Perspectiva nacionalista e conservadora da vida social cuja violência ética se dá, fundamentalmente, por sua concepção anacrônica que desconsidera o contexto na análise das questões morais que emergem no bojo das relações sociais do tempo presente. Daí Butler afirmar que "o éthos coletivo instrumentaliza a violência para manter sua aparência de coletividade” (p.15) por ignorar os 'direitos' do indivíduo. (ibidem). Para Adorno o problema da moral surge a partir da divergência entre interesses individuais (o ser em posse de suas particularidades) e universais (o ser destituído delas). Esvaziar ontologicamente a vida, tática biopolítica, nesse sentido, nada mais é que privar o sujeito do exercício de ser, de existir.

Atrelada a essa questão podemos recuperar a importante reflexão feita por Andreas Huyssen que chama atenção para a improdutividade das reivindicações normativas legais em nome da justiça feitas pelo discurso dos direitos humanos quando não considera os contextos históricos e políticos de um dado país ao idolatrar, por exemplo, a aplicação de princípios abstratos e universalizantes (2014, p.201), tal como almejado pela Declaração Universal de 1948 (idem, p.204). Essa postura, segundo Huyssen, não dá conta de amparar uma efetiva política de direitos humanos (idem, p.201) que, para ele, "sempre foi uma questão de poder e de relações assimétricas" (idem, p.202).

Mesmo fantasiado pela aparência apaziguadora de coletividade, que violenta as idiossincrasias culturais e solapa os direitos dos sujeitos (BUTLER, 2015, p.14-15), esse éthos coletivo não responde às demandas específicas das minorias que, na América Latina, por exemplo, são, em termos quantitativos, a maioria. Entretanto, o problema da moral que Adorno sinaliza existir em decorrência da tensão entre o éthos e a moral, "não é com a universalidade como tal, mas com uma operação da universalidade que deixa de responder à particularidade cultural e não reformula a si mesma em resposta às condições sociais e culturas que inclui em seu escopo de aplicação" (idem, p.17). Uma operação que desconsidera o caráter de descontinuidade intrínseco à conformação do éthos contemporâneo. (idem, p.14)

Assim, a anulação da particularidade cultural dos sujeitos ou comunidades, por exemplo, funcionaria como uma espécie de desterro ontológico fantasmagórico, tomando o termo fantasma como um ser quase vivo, quase morto, considerado mais um espectro que propriamente um ser humano. Ortiz \& Kaminker, à propósito da conceituação do termo "refugiado", cuja problemática ecoa, em certa medida, com a dos desterritorializados na Colômbia, questionam: 
Quem são os refugiados? São os corpos que sobrevivem a matanças, mutilações, cerceamentos ou prisão. E, como tais, têm em seus relatos e sobre suas costas a carga de estar distantes de sua terra, mas sobretudo de ser a prova viva da guerra. São relatos vivos de uma morte, de um aniquilamento e pesa sobre eles o ter sobrevivido. São excluídos políticos, ao lhes ser negado o direito à cidadania, expulsos de seus territórios, comunidades, coletivos e lares. Nunca será fechada sua ferida enquanto não possam decidir livremente retornar e permanecer em seu país ou conseguir se estabelecer e "estar" no país que lhes protege. (2014, p.48, grifo do autor e tradução minha)

Daí o entendimento do sistema de gestão política dos corpos das vítimas do conflito armado colombiano se pautar em sua redução, total ou parcial, levando-os à condição de seres sem história, sem passado, sem identidade; a um organismo anônimo, portanto. Sua presença, a desse espectro semihumano, assim qualificada, forçosamente destituído das condições mínimas para o exercício pleno de sua cidadania, não deixa de ser, entretanto, uma ameaça permanente pela iminência necessária de sua presença, sua sobrevivência, a qualquer momento e em qualquer lugar. $\mathrm{Na}$ arte, por exemplo.

Apesar da condição de experimentar uma morte dupla (morte física e simbólica), esse ser fantasmagórico, sobrevive às cinzas do esquecimento e da injustiça cada vez que ressurge pelas mãos de artistas que se debruçam sobre os estilhaços de seus corpos. Gesto simbólico de reconhecimento e restituição de sua condição humana, de "vida vivível”, já que a “dignidade das vítimas, suas lutas e seu destino devem ser preservados na memória, sobretudo porque era um objetivo expresso dos mestres do genocídio obliterar qualquer lembrança de suas vítimas" (HUYSSEN, 2014, p.200).

Humanização que ensaia a reintegração de suas dignidades, ao "fazer justiça por meio de sua figuração estética" (idem, p.212), estimulando uma aproximação mais concreta entre os discursos contemporâneos da memória, em particular aqui as textualizações (verbais e não verbais) sobre a guerra perpetradas por Colorado, Molano e Salcedo, objeto de estudo de minha pesquisa pós-doutoral realizada na UFMG, sob orientação da professora Dra. Sara Rojo, e as discussões suscitadas pelos defensores dos direitos humanos e da justiça. "Um elo substancial entre passado e futuro" (idem, p.196) para evitar que "a memória, sobretudo a memória traumática, se torne um exercício vazio" (ibidem). Isso porque, segundo Huyssen:

a instauração ativa de processos por violações dos direitos humanos nos tribunais também depende da força dos discursos da memória na esfera pública - no jornalismo, nos filmes, nos meios de comunicação, na literatura, nas artes, na educação e até nas pichações urbanas. 
A Argentina de hoje talvez seja o melhor exemplo de como uma nova onda de julgamentos de acusados dos anos do terrorismo de Estado surgiu de uma política pública de memória, operando através de vários grupos de ativistas da memória que empregam todos os meios de representação disponíveis (idem, p.200, grifos meus)

A (re)aparição desses seres fantasmagóricos na arte, ademais, interpõe uma questão de natureza temporal nas formas de se relacionar e compreender o presente histórico-político deste país e de que modo essa presença convoca a atualização do passado político traumático nacional, a partir da necessária ressurreição de histórias de grupos culturais ou comunidades ocultadas por estratégias universalizantes de morte física e simbólica. Mais ou menos o que defende Andreas Huyssen ao afirmar que:

o discurso dos direitos humanos e culturais deve apoiar-se em exemplos concretos de violações de direitos, interpretados no contexto de situações sistêmicas e históricas antigas, e pode ser respaldado por obras de arte que treinem nossa imaginação não só para reconhecer o que Susan Sontag chamou de a dor alheia, mas também para construir remédios jurídicos, políticos e morais contra a proliferação desenfreada dessa dor. A tragédia grega clássica foi a primeira a articular esse elo constitutivo entre a memória e os direitos: Antígona é uma peça que diz respeito não apenas às obrigações para com os mortos, mas também aos direitos dos vivos. (2014, p. 205, grifo meu)

CORPUS ARTÍSTICO:

Para a análise do corpus artístico de Colorado, Molano e Salcedo, respectivamente fotografia, literatura e performance/instalação, a partir da questão da desterritorialização compulsória, focalizaremos, aqui, as crianças e jovens como recorte do imenso contingente humano das vítimas do conflito armado colombiano para a abordagem analítica do tema. No gráfico 2, tomado da página web do Centro de Memória Histórica é possível perceber que 35\% do montante de quase 6 milhões e meio de desterritorializados colombianos está composto por menores idade. Diz ele:

... dos quase seis milhões e meio de pessoas desterritorializadas, do ponto de vista diferencial, um pouco mais de $50 \%$ da população deslocada são mulheres (3.301.848); 2.279.576 são pessoas menores de idade (das quais $\mathbf{1 . 4 8 0 . 9 8 3}$ têm menos de 12 anos); segundo os dados demográficos de 2005 , se estima que cerca de $15 \%$ do total da população afrocolombiana e $10 \%$ da população total indígena vêm sendo desterritorializada $87 \%$ da população expulsa de suas regiões vivia no campo; alguns afro e indígenas, em territórios coletivos reconhecidos pelo Estado. Em um país que tem um problema agrário persistente, com uma história marcada pelo difícil acesso à terra, se calcula que 8,3 milhões de hectares têm sido saqueadas ou abandonados

Literatura e Cinema de Resistência, Santa Maria, n. 32: Manifestações estéticas dissidentes, jan.-jun. 2019, p. 55-86. - ISSN 1679-849X http://dx.doi.org/10.5902/1679849X36012 
à força. $99 \%$ dos municípios colombianos foram expulsantes. À luz das cifras precedentes, não é excessivo caracterizar a Colômbia com uma nação desterritorializada. (2015, p.16, grifo meu)

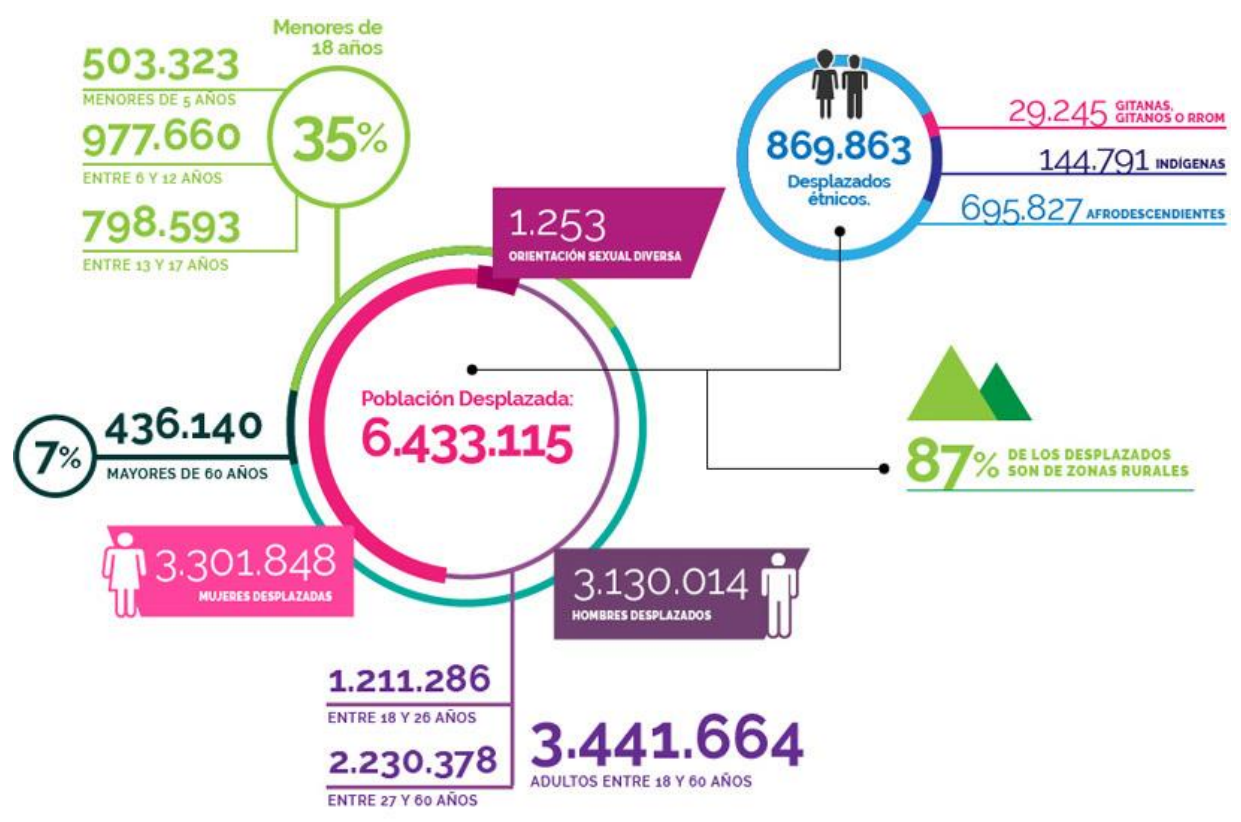

Gráfico 2. Cifras da desterritorialização na Colômbia ${ }^{18}$

O trabalho com a imagem realizado pelo jornalista e fotógrafo colombiano Jesús Abad Colorado, por exemplo, instaura uma problemática moral na medida em que aponta para a importância da particularidade do sujeito, cuja vida é para ele vivível e reconhecível, bem como de sua comunidade, seus direitos e lugares de enunciação cultural. Em suma, seu contexto, segundo Adorno (apud BUTLER, 2015, p. 13-20).

Focalizando o calvário ontológico das vítimas do conflito armado colombiano e a hercúlea força de sua resistência, podemos identificar, no recorte fotográfico de Colorado, um gesto de desinvibilização desses sujeitos por meio da instauração de uma "cena de interpelação" (BUTLER, 2015, p.70) entre esse "eu" imagético (sujeito comunitário) e o espectador (o tu), a partir não mais de sua aniquilação, morte ou apagamento, o que costuma fazer o éthos coletivo, mas do esforço pela retomada de seu protagonismo, de sua humanidade, de sua condição de ser enlutável. Para Colorado:

\footnotetext{
${ }^{18}$ Fonte: http://centrodememoriahistorica.gov.co/micrositios/desplazamientoForzado/
} 
"Dar a eles nome e rosto é dignificar e humanizar em um país que banalizou suas vidas, e no qual se priorizou muitas vezes a voz dos algozes sobre os relatos das pessoas que sofriam a peste da violência" e que "duvidou muitas vezes dos fatos e dos testemunhos das vítimas" (2015, p.10, tradução minha)

Na obra Mirar de la vida profunda ${ }^{19}$, de Colorado, seleciono aqui, quatro imagens de massacres envolvendo, direta ou indiretamente, crianças e jovens entre suas vítimas: duas referentes ao munícipio de San Carlos, localizado no Estado de Antioquia (uma de 1998 e outra de 2003), uma à Igreja Bellavista, localizada no município de Bojayá y Vigía del Fuerte, Estado de Chocó ${ }^{20}$ (2002) e a última à Comunidade de Paz de San José de Apartadó, Antioquia (2005), respectivamente.

Segundo Colorado (2015, p.212), desde os anos sessenta que os moradores do munícipio de San Carlos vêm sendo alvo da violência do conflito armado: perseguições e consequente desterritorializações de liberais, assassinatos de integrantes de movimento cívico contrário à instalação de hidroelétricas na região por grupos armados, etc., o que o torna um dos lugares mais afetados pela violência no país. E acrescenta:

Entre 1995 e 2005, a Personería Municipal registrou trinta e três massacres com duzentas e nove pessoas assassinadas, cento e cinquenta e seis desaparecidas e setenta e seis vítimas de minas antipessoas. Entre 1985 e 2010 quase vinte mil pessoas das vinte e cinco mil que havia no município foram desterritorializadas. (ibidem, tradução minha)

Na foto 1 vemos um jovem, possivelmente parente do homem assassinado, arrumando, sozinho, o corpo estendido numa maca. O gesto de humanização registrado por Colorado é, no mínimo triplo, na medida em que se concretiza não somente na captação, isto é, na seleção de uma imagem de guerra, entre milhares de outras, digna de ser arquivada, portanto circunscrita e datada, mas pelo ritual de luto em si, iniciado pela criança, bem como pelas infinitas rememorações dessa morte cada vez que chegar aos "olhos" que diante dela se colocarem. Depreende-se desse triplo movimento humanizador (do artista, da criança e do espectador interpelado pela imagem) respeito e reconhecimento da singularidade dessa vida perdida. Um corpo, de Manuel Eduardo Salazar, vale a pena reforçar, diante do qual nos colocamos também em posição de luto. A arte, a partir desse exemplo, revela duplamente,

\footnotetext{
${ }^{19}$ Nas palavras de Colorado: “Ao publicar este livro, completo vinte e cinco anos de estar fazendo um registro para a memória” (2015, p.10, tradução minha)

${ }^{20}$ Região considerada com a maior biodiversidade do planeta e a mais chuvosa.
} 
como queria Huyssen, sua força simbólica e concreta enquanto dispositivo de memória e de luta pelos direitos humanos.

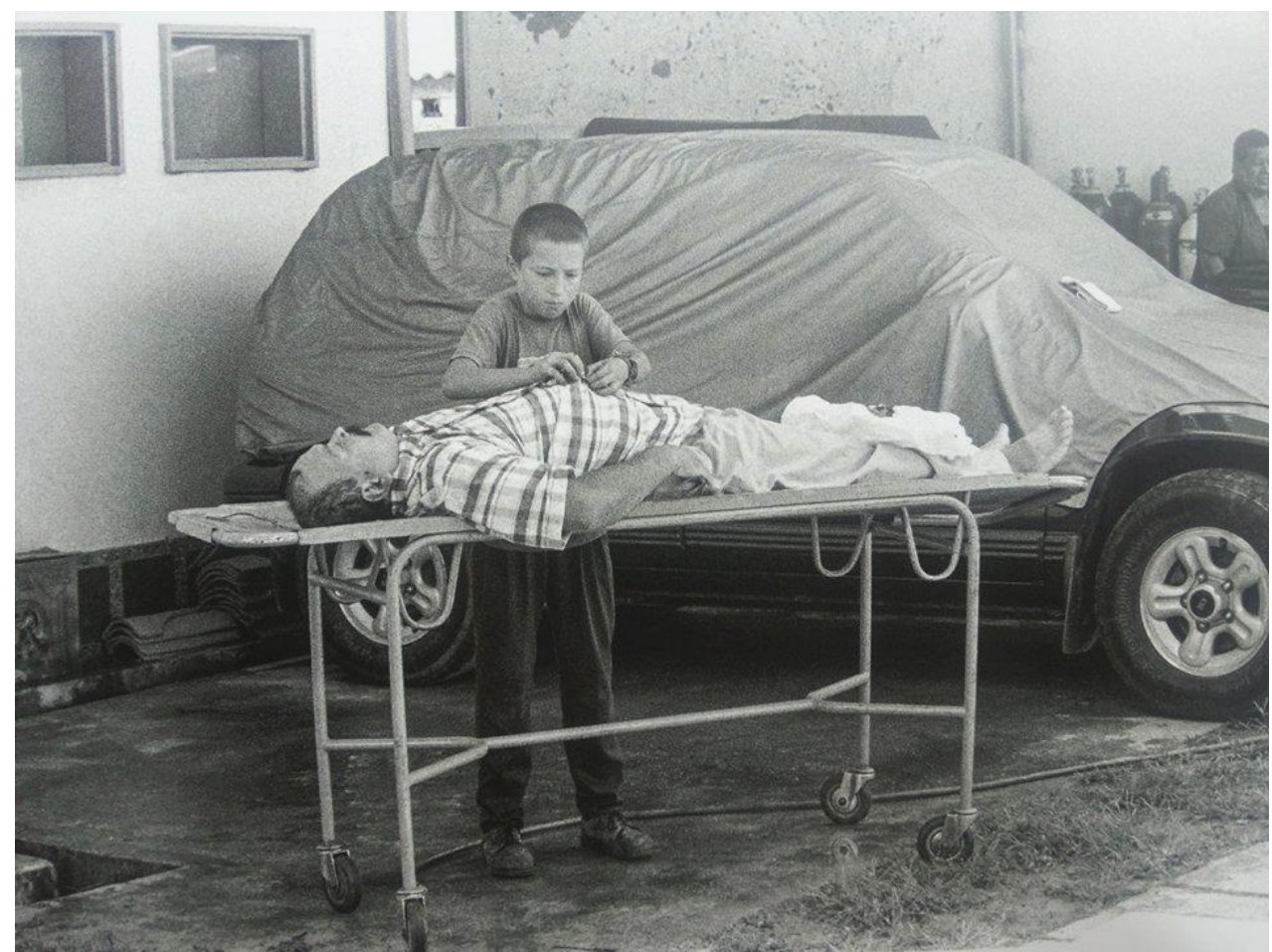

Foto 1: Eduardo Salazar assassinado por paramilitares das AUC com treze pessoas mais, San Carlos, Antioquia, 25 de outubro de 1998. (COLORADO, 2015, p.147)

A imagem captada da pequena Karina, à frente de seu pai Misael, no ano de 2003 em San Carlos, abandonando lar, escola, comunidade, animais, etc. traduz paradoxalmente a condição de vulnerabilidade material e física de certas vidas humanas, provocada compulsoriamente por um Estado de Guerra, mas ao mesmo tempo a hercúlea força do desejo da continuidade da existência em família por essas mesmas vidas. Em primeiro plano vemos a menina que parece correr, sugestão que oferece o desenho de seu braço esquerdo, enquanto o corpo de seu pai se inclina heroicamente (predicado potencializado pela saliência da ossatura de seu peito que me faz aproximá-lo do Cristo carregando a cruz, maltratado pelos seus semelhantes e cruelmente crucificado) para transportar uma geladeira. Uma geladeira!? Karina leva convicta uma bolsa e despende nesse gesto mais força do que possivelmente necessitaria para carregá-la, talvez porque dentro dela contenha mais vínculo familiar e comunitário, ancestralidade, costumes e saberes (marcas da personificação e singularidade dessas vidas) que simplesmente dinheiro. 
Sobre esse massacre em particular e acerca da condição precária da vida humana dos habitantes dessa comunidade definida pelos atores do conflito armado um dado contextual que talvez ajude a compreender, ainda que superficialmente, a pressa de Karina e a força monumental despendida por seu pai:

A nona frente das FARC percorreu as veredas de La Tupiada, Dinamarca e Dosquebradas em busca das casas que tinham telefones e assassinaram dezessete pessoas, acusando-as de serem cúmplices dos paramilitares e do exército. Entre as vítimas havia jovens que não quiseram entrar em suas filas, uma mulher grávida e duas pessoas maiores de setenta anos. (ibidem, tradução minha)

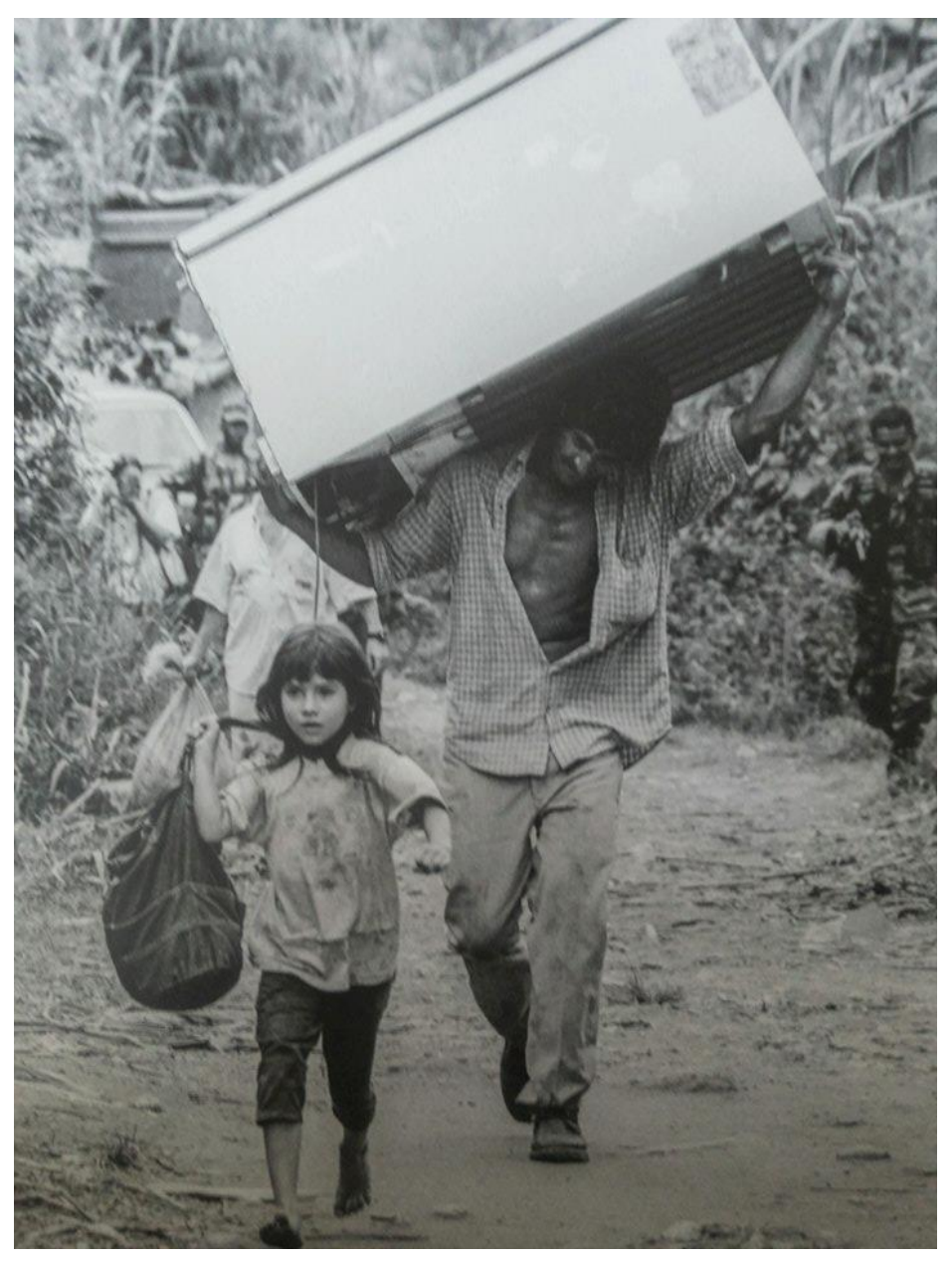

Foto 2: Karina e seu pai Misael fogem da vereda La Tupiada após o massacre das FARC no qual assassinaram dezessete camponeses, San Carlos, Antioquia / janeiro de 2003 (idem, p.118) 
O saldo de mortos na Igreja Bellavista (foto 3), após o lançamento de um cilindro bomba durante o conflito entre guerrilheiros do Bloco Jose María Córdoba das FARC e os paramilitares do Bloco Elmer Cárdenas das Autodefensas Unificadas de Colombia, foi de 79 pessoas, em sua grande maioria afrocolombianos e indígenas da região do rio Atrato e do Departamento de Chocó, entre as quais quarenta e oito, portanto mais da metade, eram menores de idade.

Depois de vários dias de tensão, a guerrilha lançou um cilindro bomba contra os paramilitares que se escondiam nas proximidades da igreja e do hospital. O artefato caiu no altar do templo. Os fatos geraram a desterritorialização de milhares de pessoas de distintas comunidades que estavam suportando cinco anos de bloqueios alimentícios e de assassinatos por parte dos grupos armados. (idem, p.216, tradução minha)

Segundo o Centro Nacional de Memoria Histórica: "Este crime de guerra evidenciou a violação de todas as normas do Direito Internacional Humanitário pelos grupos armados, assim como as falhas do Estado colombiano em sua obrigação de velar pela integridade desta comunidade" 21 . Precisamente o que nos alerta Colorado quando, em entrevista a Álvaro Restrepo, afirma que "a institucionalidade não pode se comportar no mesmo nível que os delinquentes” (idem, p.19).

Apesar de não haver nenhum corpo materialmente presente no registro fotográfico escolhido, ele revela, não obstante, a presença irrevogável de todas as pessoas que ali estiveram nesse espaço comunitário sagrado, não somente por meio da imagem do Cristo mutilado, em primeiro plano, mas por cada destroço espalhado pelo chão do templo. Assim dispostos no enquadramento fotográfico, eles oferecem uma medida simbólica (mas não por isso desprezível) do desespero, do desamparo e da brutalidade perpetuados por esse massacre. Oferece também uma ritualística de sepultamento coletivo desses corpos, assim com foi o seu extermínio, que ao enfatizar o elo comunitário de pertença entre eles, não deixa de demandar o desejo de afagar, de acariciar cada nome, cada história ali brutalmente interrompida.

${ }^{21}$ http://www.centrodememoriahistorica.gov.co/micrositios/expo_itinerante/. Acesso em 20 de setembro de 2016. 


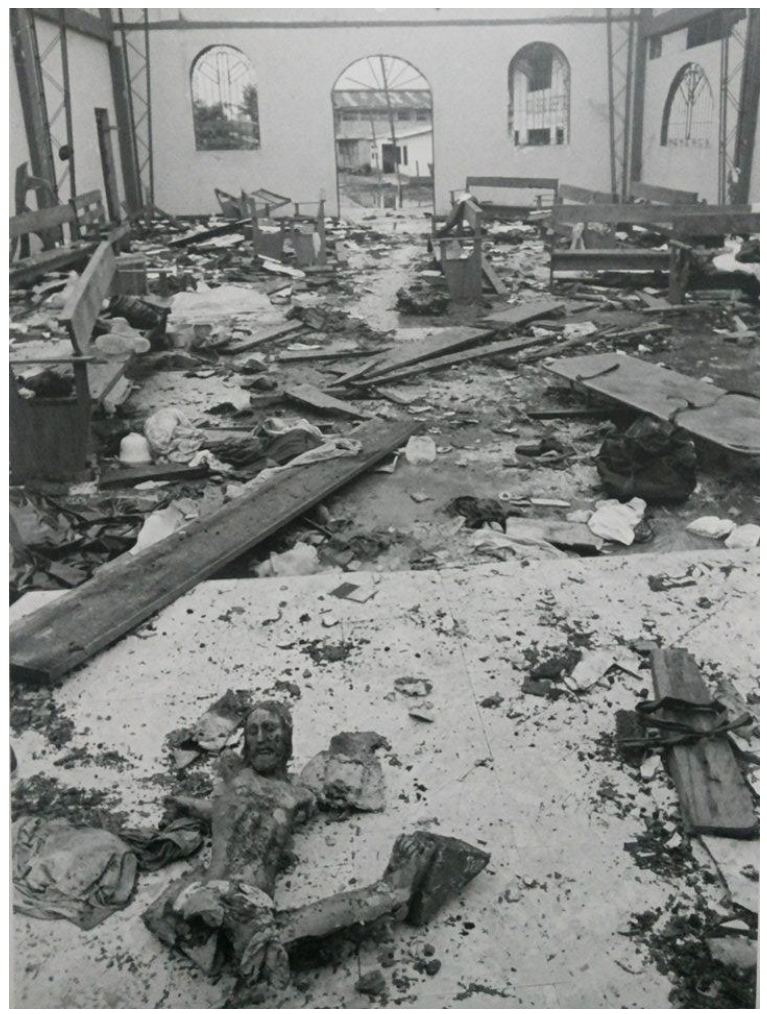

Foto 3: Igreja de Bellavista, Bojayá, Chocó, 6 de maio de 2002. (idem, p.61)

A imagem a seguir também possui caráter memorialístico polivalente: o lugar sobre o qual a criança se refugia para chorar é um monumento às vítimas, algumas das quais se pode ler nitidamente os nomes, construído pela comunidade de Paz de San José de Apartadó, em 2005. Entre eles, Deiner Guerra, de onze anos, Santiago, de vinte meses e Natalia de seis anos. O primeiro filho de Luis Eduardo Guerra e Beyanira Areiza, também assassinados e os dois últimos, filhos de Alfonso Bolívar e Sandra Muñoz, igualmente abatidos. Após desterritorialização forçada da referida comunidade a Sanjosesito, o monumento foi vergonhosamente profanado e destruído pelas forças públicas. A comunidade decidiu então recordar suas vítimas por meio de uma atividade permanente, chamada "Piedras móviles", que figura no currículo escolar das crianças, a partir da qual os nomes de seus mortos são pintados em pedras e dispostos sob uma árvore, em cima da qual foram colocados restos de suas exumações. ${ }^{22}$

\footnotetext{
22 https://www.centrodememoriahistorica.gov.co/multimedias/MemoriasExpresivasRecientes/Memoria_H/antioquia/piedr as/index.html. Acesso em 27 de fevereiro de 2017.
} 


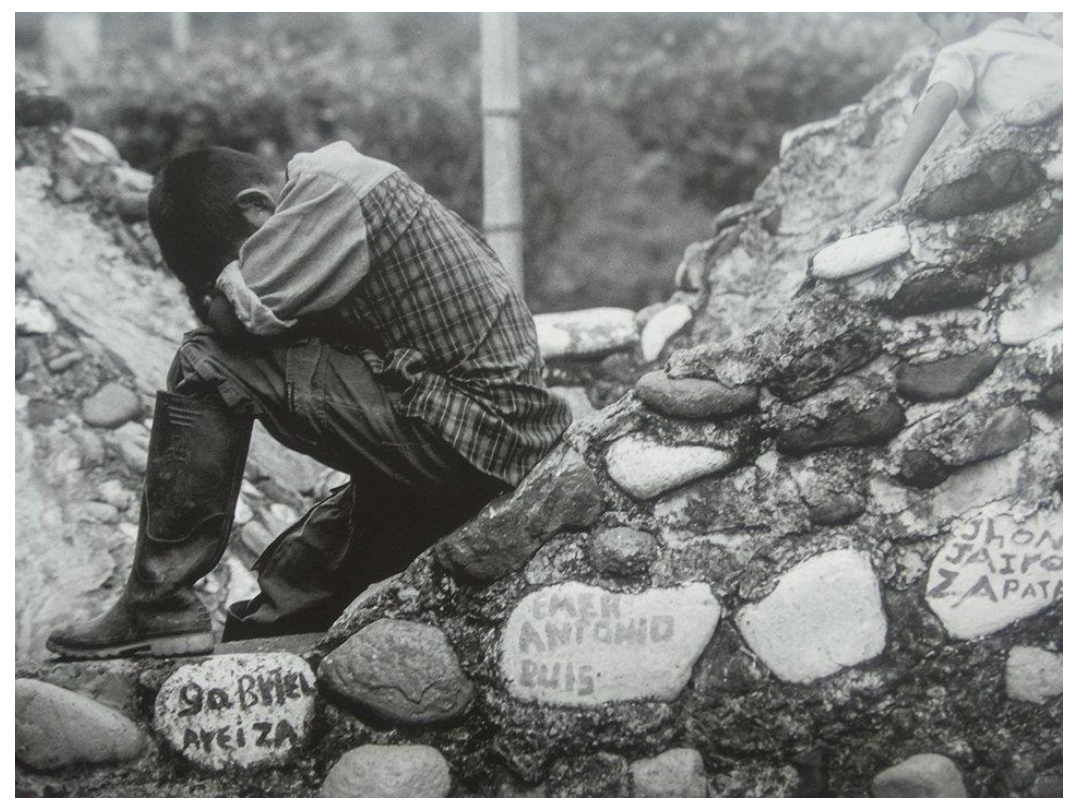

Foto 4: Monumento às vítimas. Durante o velório das famílias assassinadas pelo exército e paramilitares. San José de Apartadó, Antioquia, 28 de fevereiro de 2005. (idem, p.154)

Segundo Arturo Escobar, a resistência dessas comunidades a esta Empresa mortuária na Colombia, cujo objetivo é fagocitar a diversidade de mundos e reduzi-los a apenas um, está fundada num sentido ontológico e ancestral de ocupação do território sem o qual o sentido da vida se reduz a nada porque:

A perseverança das comunidades e movimentos de base étnico-territoriais envolvem resistência, oposição, defesa e afirmação, mas com frequência pode ser descrita de forma mais radical como ontológica. Igualmente, ainda que a ocupação de territórios coletivos usualmente envolva aspectos armados, econômicos, territoriais, tecnológicos, culturais e ecológicos, sua dimensão mais importante é a ontológica. Neste marco, o que "ocupa" é o projeto moderno de Un Mundo que busca converter os muitos mundos existentes em um só; o que persevera é a afirmação de uma multiplicidade de mundos. Ao interromper o projeto globalizador neoliberal de construir Un Mundo, muitas comunidades indígenas, afrodescendentes, e camponesas podem ser vistas como adiantando lutas ontológicas (2014, p.76, grifos do autor)

Por esse motivo que é indubitavelmente poderoso o gesto da comunidade de Paz de San José de Apartadó em reinventar, uma e outra vez, se preciso for, as formas de vivência do luto de seus mortos, ainda que deles tenha sido (provisoriamente?) expropriado o solo sagrado de seu território. Faz parte de sua luta ontológica, especialmente das comunidades indígenas e afrodescendentes colombianas, resistir ao extermínio, físico e simbólico. A um etnocídio de Estado que tem, senão a participação declarada, por meio de ações deliberadas do Exército Nacional, em inúmeros massacres, um tipo de vinculação ainda mais perversa desenhada pela omissão e pela absoluta negligência política 
do Governo no que concerne ao respeito e aplicação dos preceitos da Carta Constitucional de 1991, entre os quais figuram, ironicamente, nos artigos 11 a 13 a disposição de proteção à vida, à igualdade e à liberdade de sua população. Sobre isso afirma Clastres em consonância com o que afirmou anteriormente Arturo Escobar:

o etnocídio resulta na dissolução do múltiplo no Um. O que significa agora o Estado? Ele é, por essência, o emprego de uma força centrípeda que tende, quando as circunstâncias o exigem, a esmagar as forças centrífugas inversas. O Estado se quer e se proclama o centro da sociedade, o todo do corpo social, o mestre absoluto dos diversos órgãos desse corpo. Descobre-se assim, no núcleo mesmo da substância do Estado, a força atuante do Um, a vocação de recusa do múltiplo, o temor e o horror da diferença. Nesse nível formal em que nos situamos atualmente, constata-se que a prática etnocida e a máquina estatal funcionam da mesma maneira e produzem os mesmos efeitos: sob as espécies da civilização ocidental e da alteridade, o sentido e o gosto do idêntico e do Um. (2004, p.59-60)

A instalação performática Plegaria muda (2009), de Doris Salcedo, chama atenção para o caráter de "morte social" ou "morte em vida" de sujeitos marginalizados, tanto os que vivem nos subúrbios de Los Angeles quanto os das cidades colombianas. Por ser a Colômbia, segundo ela, "o país da morte insepulta, da vala comum e dos mortos anónimos” (2012, p.29), essa obra objetiva "confrontar-nos com o pesar contido e não elaborado, com a morte violenta quando reduzida à sua total insignificância e que faz parte de uma realidade silenciada como estratégia de guerra" (ibidem). Estratégia que seleciona morbidamente vidas humanas para servirem de meros fantoches, absolutamente prescindíveis e substituíveis, num jogo macabro cujos envolvidos-responsáveis estão única e exclusivamente ocupados em atender a interesses políticos e econômicos. Plegaria muda, nesse sentido, é para Salcedo uma "tentativa de elaboração desse luto", de recordação dos "nossos mortos" (idem, p.30), do reconhecimento "do valor de cada vida perdida e a singularidade irredutível de cada túmulo" (ibidem). Um esforço artístico e humano, portanto, que responde integralmente ao chamado político-humanitário feito por Butler e Huyssen, por "evocar e restituir a cada morte a sua verdadeira dimensão, permitindo assim o retorno à esfera do humano destas vidas dessacralizadas" (ibidem).

A construção de Plegaria muda, assim como a maioria das obras da artista colombiana, parte da escuta da história de dor e sofrimento de testemunhas, vítimas de violência, e se refere

a um acontecimento específico que teve lugar na Colômbia, entre os anos 2003 e 2009, quando cerca de 1500 jovens provenientes de zonas marginais foram assassinados pelo Exército colombiano sem motivo aparente. Contudo, era notória a existência de um sistema de

Literatura e Cinema de Resistência, Santa Maria, n. 32: Manifestações estéticas dissidentes, jan.-jun. 2019, p. 55-86. - ISSN 1679-849X http://dx.doi.org/10.5902/1679849X36012 
incentivos e benefícios fomentado pelo Governo colombiano caso o Exército apresentasse um número maior de guerrilheiros mortos em combate. Colocado perante este sistema de prémios e incentivos, o Exército começou a contratar jovens de zonas remotas e marginais, oferecendolhes trabalho e transportando-os de imediato para outros locais onde eram assassinados e apresentados como "guerrilheiros não identificados mortos em combate". (ibidem)

Plegaria muda é, portanto, um gesto simbólico de redenção do estado de silêncio e de invisibilidade violentamente impostos a esses 1500 jovens colombianos, mas não apenas a eles já que, por ir na contramão do representacional, da ilustração ou do meramente documental, possui caráter anacrônico, potência capaz de dialogar com o sofrimento de outros marginalizados, de outras tragédias para além das perpetradas no violentado solo latino-americano. Sobre isso diz Isabel Carlos:

No decorrer destes dois anos, de 2009 a 2011, a artista, subtilmente, foi-me chamando a atenção para o que se estava a passar na Espanha, com centenas de famílias a quererem resgatar os corpos dos mais de cem mil desaparecidos durante a Guerra Civil e que tinham sido lançados em valas comuns. Ou o que acontecia na Bósnia, onde os familiares dos (sic) milhares de pessoas massacradas em Srebrenica, em 1995 - o maior genocídio europeu depois da II Guerra Mundial -, continuavam em busca dos corpos das vítimas, pois desconheciam o local de enterramento ou qual o seu destino final. (idem, p.61)

As 169 peças que compõem a referida performance/escultura/instalação, dispostas em um monumental conjunto orgânico (um verdadeiro campo santo), estruturado por repetição, têm comprimento e largura de um caixão e evocam, segundo Mieke Bal, todas as vidas que foram privadas "da sua humanidade quando os seus corpos não podiam ser encontrados, enterrados e chorados" (idem, p.87) e que foram assassinadas em massa. Ocultação tomada como "segunda morte" (ibidem), como tática que reifica a cruel distinção entre vidas passíveis e não passíveis de luto. No entanto, afirma Moacir dos Anjos:

Mesmo sem trazer a identificação de nome algum, a mera ordenação dos lugares de sepultamento resgata os mortos do anonimato e da amnésia social a que a vala repartida e o enterro escondido de corpos os condenam, devolvendo a cada vida tomada a ideia de irredutível particularidade. (idem, p.143)

Cada peça está composta por duas mesas de madeira acinzentadas, de igual tamanho, unidas por uma massa compacta de terra a partir da qual germina matéria viva, uma erva que cresce lentamente entre as fissuras presentes na madeira: um contraste rítmico, segundo Mieke Bal, face à "rapidez do massacre" (idem, p.99). Esse movimento da vida marginalizada que resiste à opressão e encontra espaços possíveis, quase sempre mínimos, irrisórios, de resistência à morte ou até mesmo de 
renascimento, refazimento modela uma corporeidade viva que sobrevive a pesar de. Daí serem as peças consideradas como "criaturas" (idem, p.59) por Isabel Carlos que "mostram simultaneamente a morte - estão sepultados e frios - e a perseverança da vida" (idem, p.95). "Uma pregação ou oração muda por aqueles que são vítimas e sujeitos de violência, um elogio da vulnerabilidade que nos confronta com a nossa condição humana de seres simultaneamente frágeis mas capazes de violência extrema" (idem, p.63)

Para Adorno não há moral sem um “eu”, sem um “si-mesmo” (apud BUTLER, 2015, p.16). Se há um esforço de "indigentizar", isto é, de tornar indigente um sujeito pela privação violenta do seu lar ou território, localidades a partir das quais ele exercita seu sentido de identidade, de coletividade, a invenção de uma cena simbólica, no campo da arte, que problematize e ilumine a questão moral subjacente ao apagamento cultural e existencial de um determinado grupo étnico-cultural se faz relevante na medida em que protagoniza o que o éthos coletivo tenta colocar debaixo do tapete. Ação higienista e violenta de vida social que reduz certos grupos sociais à condição de seres sem nome, sem passado ou história. De vidas não enlutáveis, segundo Butler.

A latência do passado no anacronismo temporal/contextual suscitado pelas imagens de Colorado possibilita a sobrevivência do caráter memorialístico da imagem fotográfica ao mesmo tempo que dá conta do retrato de uma temporalidade histórico-política específica marcada pelo solapamento de direitos civis e pela violação de direitos humanos. Esse duplo dilatamento do registro fotográfico, que excede o "si mesmo" temporal e contextual de seus registros, isto é, seu recorte histórico, garante a permanente atualidade ou possibilidade de atualização da imagem, gesto necessário para o importante exercício de identificação que pode decorrer da interpelação entre imagem e espectador. Por meio dela, são disparados a autorreflexão e o reconhecimento social, duas práticas que, segundo Judith Butler, "são essenciais para qualquer relato substantivo da vida ética". (idem, p.69)

O trabalho com a imagem em Colorado e com a arquitetura/instalação performática de Salcedo se destacam, portanto, pelo duplo nível de interpelação que desenvolve. Seu valor ético reside na faceta dinâmica de estabelecer uma cena conversacional com seu espectador, alternando entre o "relato" localizado e pontual de vivências traumáticas experenciadas por sujeitos ou comunidades específicos e uma textualização imaginária a partir da qual questões morais e éticas que extrapolam delimitações geográficas são suscitadas, tais como: a banalização da vida, a despersonificação, a

Literatura e Cinema de Resistência, Santa Maria, n. 32: Manifestações estéticas dissidentes, jan.-jun. 2019, p. 55-86. - ISSN 1679-849X http://dx.doi.org/10.5902/1679849X36012 
invisibilização e a desumanização dos sujeitos por meio da cotidianização da violência e da desresponsabilização dos crimes de violação de direitos humanos.

Por essa razão que as obras de arte aqui apresentadas desenham um gesto necessário, porque propõem aos espectadores que ajam, que se posicionem diante da urgência da necessidade de restituição da humanidade das vítimas da violência do conflito armado colombiano. Proposição artístico-política que reivindica abertamente a dimensão ontológica do ser, de sua dimensão enlutável, de sua presença enquanto ser vivível, enquanto vida reconhecível, que comporta memórias, afetos e vínculos comunitários.

O primeiro texto, intitulado Desde el exilio, do livro Desterrados: crónicas del desarraigo, Alfredo Molando conta sua conturbada trajetória como jornalista na Colômbia e as sistemáticas ameaças sofridas ali que o levaram ao exílio na Espanha. Condição à qual não se sente confortável, quando afirma: "Não me acomodarei nunca ao exílio, ainda que tenha que dizer hoje que essa pequena morte, feita sempre de estranhamentos, não começa com as ameaças dos inimigos, mas sim com o silêncio dos amigos" (2001, p.26). Subjaz dessa afirmação, semelhante à energia que move o trabalho de Colorado e Salcedo, um compromisso com a verdade e com o sujeito. Daí estar todos os textos de seu livro baseados na experiência pessoal de vítimas diretas do conflito armado colombiano, numa tentativa de enfrentar a dicotomização da vida e restaurar a dimensão do sujeito solapada por uma política cujo esforço maior é borrar do mapa um país com uma extensão territorial de mais de 1 milhão de quilômetros quadrados e quase 50 milhões de habitantes.

\begin{abstract}
Molano decidiu retratar em sua literatura um país esquecido e desprotegido, cuja existência para as classes dirigentes, empenhadas em passar uma boa imagem internacional, não lhes convém admitir que existe. Retratou a cara humana do narcotráfico e o abandono por parte do Estado das pessoas mais sem posses. São muito mais convenientes, para todo discurso político, as dicotomias: bons e maus, terroristas e vítimas. A narrativa de Molano explode o binarismo simplista do discurso do poder. Seu olhar não é nem condescendente, nem satanizador. Molano lembra o leitor que o camponês não é um ser nem decorativo nem a-histórico nem apolítico: é um indivíduo. ${ }^{23}$
\end{abstract}

O livro de Molano está composto por oito crônicas, todas construídas a partir do relato de testemunhas do permanente estado de guerra instaurado há décadas na Colômbia. O segundo texto tem como protagonista uma criança chamada Angela, de nove anos, nome que dá título à crônica. A

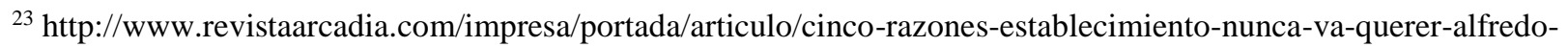
molano/32149. Acesso: 18 de julho de 2016. Tradução minha.
} 
metáfora dos pés descalços, imagem que vincula afetivamente a menina à sua terra natal e que dá início à narrativa contrasta com o desejo infantil de possuir um par de tênis vermelho, anunciado na TV, quando passou a viver, compulsoriamente, na capital (Bogotá), após sua família ter sido expulsa pela disputa entre guerrilha e grupos paramilitares. Uma violenta realidade que alterava drasticamente o cotidiano da comunidade.

Uma vez quando estávamos com meu pai fazendo uma viagem de barco por Nechí, uns homens nos chamaram da margem; usavam uniformes como os da polícia, mas não eram policiais porque não carregavam cassetete atado à cintura, mas escopetas grandes. Eram vários e meu pai foi ver o que queriam. Disseram a ele que fizesse o favor de passar para o outro lado do rio. Fizemos a travessia porque, como disse meu pai, com pessoas armadas a coisa não é de favores e sim de obrigações. (MOLANO, 2001, p.40, tradução minha)

Em Nechí, sua comunidade natal e da qual foi forçosamente arrancada, Angela tinha de "um tudo": um jardim que dava volta na casa construída pouco a pouco e a duras penas pelo pai; peixes coloridos para brincar e pescar, animais de estimação (o Lauro e uma gatinha sem nome); escola, primos, avós, tios e inúmeros amigos na comunidade; alimentos em abundância que eram colhidos da horta familiar e, às vezes, vendidos para os vizinhos; um pai que a amava e a protegia e, principalmente, liberdade para ir e vir. Para ser.

Em Nechí nunca usei sapatos e andava com os pés descalços como meus irmãos, meus primos e quase toda a comunidade. Não necessitávamos deles porque lá o que não é areia é barro; muito menos precisei usá-los quando tive bolhas nos pés e eles ficaram sensíveis. Lá eu gostava de andar descalço pelo bairro e nunca fiquei doente, como afirmam que se fica por não usar sapatos. (idem, p.35, tradução minha)

Lá no terreno da casa pegava tudo: pimenta, tomate, limão, mamão, mandioca. Comíamos tudo e às vezes tinha até para os vizinhos. Quando a colheita chegava, minha casa se tornava uma loja e todos iam comprar uma coisa e outra. Em Nechí era só esticar a mão e colher. (idem, p.42, tradução minha)

A vida dura de trabalho, porém feliz da família de Angela Maria, era quase sempre perturbada pela iminência da presença dos atores envolvidos no conflito armado que alterava drasticamente o ritmo e o modo de vida das pessoas de sua comunidade, exigindo delas obediência absoluta a partir da instauração desumana e descabida do medo da morte provocado, quase sempre, por 
homens de moto [que] passavam por cima e estragavam tudo com seus pneus e com suas botas. Nós não podíamos falar nada, nem olhá-los feio, porque nossos pais tinham avisado que eles eram da paramilitar, gente que quando ficava brava matava pessoas. Eu nunca vi as armas deles, porque eram pequenas e eles a usavam escondidas nas mochilas. Os adultos tinham medo deles. Meu pai me dizia que não perguntasse nada deles e nem sequer os mencionasse. Também estava proibido falar da guerrilha e entrar nas reuniões dos evangélicos que eu adorava porque cantavam e cantavam todo dia. (idem, p.39, tradução minha)

Os pés descalços, sem impedimentos de qualquer ordem pra que Angela fosse capaz de ir, vir e ser, numa Nechí sem a presença da violência da guerra representava uma possibilidade mais concreta de a criança exercer sua existência enquanto ser vivível, porque esse contexto reunia as condições (materiais, sociais, culturais e afetivas) que necessitava para usufruir efetivamente sua condição humana. Numa Bogotá violenta e adversa, que lhe encerrava desumana e compulsoriamente, junto com outras pessoas, num espaço doméstico minúsculo, restava à pequena criança desejar os tênis vermelhos anunciados na TV. Talvez na ilusória esperança de reencontrar e resgatar parte da alegria que experimentava quando, numa Nechí livre, andava de pé no chão, sentindo a textura e a temperatura da Terra.

O que eu gosto de Bogotá é a televisão, que aqui é colorida e em Nechí era preta e branca. Aqui eu durmo às dez, mas estou esquentando meu lugar desde oito. Não nos tem faltado nada porque meu pai trabalha levantando parede numa obra. Sai às quatro da manhã e volta às nove da noite. Por isso a gente come todo dia, e quando há dinheiro ele compra tudo para nós. Ele me prometeu uns tênis vermelhos como os do ratinho que aparece na televisão, e eu creio que vou ganhá-los. Os sapatos que tenho me apertam e por isso agora já são da minha irmã. Choro quando tenho que usá-los. Em Nechí nunca chorava, só quando eu caia ou ralava, e isso quase não acontecia. (...)

(...) Eu acho que lá conseguíamos mais fácil o de comer e mais difícil a roupa e os sapatos. Aqui conseguimos roupa e sapatos, mas a comida é bem mais difícil. (idem, p.49-50)

O esforço humanizador perpetrado por Colorado, Molano e Salcedo, nas obras aqui analisadas, mas igualmente em todo o trabalho artístico que realizaram até hoje, revela, portanto, a importância que a arte tem enquanto dispositivo discursivo de memória para fazer frente (enfrentar, contestar, problematizar, publicizar, denunciar...) à afirmação feita por Judith Butler posta na epífrage deste trabalho. Se "parte do problema da vida contemporânea é que nem todo mundo conta como sujeito", diz ela, sabemos, pelo esforço desses três artistas, que há inúmeras possibilidades - gesto necessário e com certeza sempre insuficiente - de recobrar sacralidade, humanidade e dignidade em torno das vidas humanas perdidas em contextos de extrema violência como é o caso vivenciado pela população colombiana. 


\title{
REFERÊNCIAS
}

\begin{abstract}
ALTO COMISIONADO DE LAS NACIONES UNIDAS PARA LOS REFUGIADOS (ACNUR). Situación Colombia: indígenas. $2012 . \quad$ Disponível em: http://www.acnur.org/t3/fileadmin/Documentos/RefugiadosAmericas/Colombia/2012/Situacion_Col ombia_-_Pueblos_indigenas_2012.pdf?view=1. Acesso em: 10 de janeiro de 2016.
\end{abstract}

BUTLER, Judith. Relatar a si mesmo: crítica da violência ética. Tradução de Rogério Bettoni. Belo Horizonte: Autêntica, 2015.

BUTLER, Judith. Quadros de guerra: quando a vida é passível de luto? Tradução de Sérgio Lamarão e Arnaldo Marques da Cunha. Rio de Janeiro: Civilização Brasileira, 2016.

CASTROS, Eduardo Viveiros de. A inconstância da alma selvagem: e outros ensaios de antropologia. São Paulo: Cosac Naify, 2002.

CLASTRES, Pierre. Arqueologia da violência: pesquisas de antropologia política. Tradução de Paulo Neves. São Paulo: Cosac Naify, 2004.

COLORADO, Jesús Abad. Mirar de la vida profunda. Bogotá: Editorial Planeta Colombiana, 2015.

Corporación de Servicios Jurídicos Profesionales Comunitarios SEMBRAR. Cuaderno Colombia: Violencia y Derechos Humanos. Paz con Dignidad, 2005. Disponível em: http://www.revistapueblos.org/old/spip.php?article788. Acesso em: 24 de fevereiro de 2016.

DELGADO, Sergio Coronado. Derecho a la tierra y al territorio. Ediciones Ántropos Ltda.: Bogotá, 2009.

ESCOBAR, Arturo. Sentipensar con la tierra. Nuevas lecturas sobre desarrollo, territorio y diferencia. Medellín: Ediciones UNAULA, 2014.

GAMBOA, Santiago. La guerra y la paz. Bogotá: Peguin Random House Grupo Editorial S.A, 2014.

GMG. ¡BASTA YA! Colombia: Memorias de guerra y dignidad. Bogotá: Imprenta Nacional, 2013.

HUYSSEN, Andreas. Os direitos humanos internacionais e a política da memória: limites e desafíos. In: Culturas do passado-presente: modernismo, artes visuais, políticas da memória. Rio de Janeiro: Contraponto, 2014. p. 195-213.

MOLANO, Alfredo. Desterrados: crónicas del desarraigo. Bogotá: El Áncora Editores, 2001. 
ORTIZ, Diana \& KAMINKER, Sergio. Suramérica y los refugiados colombianos. Revista Interdisciplinar Mobil. Hum., Brasília, Ano XXII, n. 43, p. 35-51, jul./dez. 2014. Disponível em: http://www.scielo.br/pdf/remhu/v22n43/v22n43a03.pdf. Acesso em 01 de maio de 2016.

PISMEL, Matheus Lobo \& CHAGAS, Rodrigo Simões. Colômbia: movimentos pela paz. Disponível em:

https://repositorio.ufsc.br/bitstream/handle/123456789/125574/COL\%C3\%94MBIA\%20Movimentos $\% 20$ pela\%20paz\%20-\%20TCC\%20Matheus\%20e\%20Rodrigo.pdf?sequence=1. Acesso em $24 \mathrm{de}$ novembro de 2016.

SABOGAL, Myriam Hernández [et al.]. Una nación desplazada: informe nacional del desplazamiento forzado en Colombia. Bogotá: Centro Nacional de Memoria Histórica, 2015. Disponível em: http://centrodememoriahistorica.gov.co/micrositios/desplazamientoForzado/\#myAnchor1. Acesso em 10 de agosto de 2016.

SAID, Edward W.. Reflexões sobre o exílio. In: Reflexões sobre o exílio e outros ensaios. Tradução de Pedro Maia Soares. São Paulo: Companhia das Letras 2003. p. 46-60.

SAFATLE, Vladimir. O circuito dos afetos: corpos políticos, desamparo e o fím do indivíduo. São Paulo: Cosac Naif, 2015.

SALCEDO, Doris. Plegaria muda. Munich: Prestel Publishing, 2011.

SUESCÚN, Armando. Bases militares estadounidenses en Colombia. In: La Hojarasca, n. 46, diciembre/enero de 2010. Disponível em: http://www.escritoresyperiodistas.com/NUMERO46/armando.htm. Acesso em 16 de agosto de 2015.

Recebido em 11 de dezembro de 2018

Aceito em 28 de dezembro de 2018 